siderable improvements in the performance of yeasts have been made by strain selection and, more recently, by the production of new hybrid strains. Yeast appears to have an advantage over other organisms in that its haploid generation can have a free existence, and may be tested, so that a selection of the best haploids may be used for hybrid production. This apparent advantage is largely illusory, as any character except the very simplest may be governed by many genes, so that the ability of a diploid cannot be judged by the separate abilities of its haploid compononts. The best mothod of finding better strains may therefore be to screen large numbers of randomly produced hybrids. Several producers of baking yeast have already found artificially produced yeast hybrids which are superior to naturally occurring strains, but apparently no other industry has yet used yeast hybrids commercially. Nor have polyploid yeasts been used commercially, though they have attractive qualities in that they are larger, ferment faster, and give higher yields than diploid yeasts.

The fermentation of various sugars, such as maltose, sucrose, raffinoso and galactose, is under simple genetical control in yeasts, and this has recently been found to extend to the fermentation of maltiotriose, dextrin and starch. Practically any selection of carbohydrate-fermenting abilities could be combined in one yeast, with possible applications both in industry and also for isolation of the individual enzymes.

It is very disconcerting if an industrial yeast changes its properties ; fortunately this is very rare, but brewing yeast does occasionally change its flocculation characteristics. The ability to flocculate is controlled by from one to three pairs of dominant genes which are more than ordinarily subject to mutation. Flocculation generally requires calcium ions, sometimes alcohol, is inhibited by mannose, maltose or glucose, but not by mannitol, raffinose or fructose, is dependent on $p \mathrm{H}$ and on surface tension, and sometimes is achieved only when another mutually flocculent yeast is present. All this is known, but there is much that is not known about the phenomenon and we have not yet got complete control of the balance between too intense and too weak flocculation, either of which may cause technical difficulties. A recent innovation is the deliberate use of two yeast cultures, one flocculent and one dispersed, in a brewery, with control by adjustment of the percentage of each in the mixture used for brewing.

The balance between respiration and fermentation is of importance both to producers of yeast and to industries dependent on the products of fermentation. For the former, intense exponential aeration and exponential feeding give the maximum production of yeast for the amount of carbohydrate used, with no alcohol in the residue. For the latter, aeration is necessary to keep the yeast healthy and vigorous, but too much aeration would lead to loss of alcohol production, so that just the correct amount of aeration is essential.

In a short but lively discussion the comparative values of protein extract from grass and of food yeast were questioned. The flavour of the former was stated to be sickly and unpleasant and the texture of the latter did not compare favourably with roast beef, so that in communities which enjoyed a good mixed diet neither was likely to appeal ; but where dietary protein was low either might form a valuable additive, if not a main course. The function of glycogen in the yeast cell was admitted to be still a mystery, while the aerobic fermentation of glucose by osmophilic yeasts was probably due to a shunt from the main system into one of the many alternative pathways.

\section{R. B. GILliLand}

\title{
UNIVERSITY APARTHEID IN SOUTH AFRICA
}

$\mathrm{T}$ HE proposals of the South African Government to enforce racial segregation at the universitylevel and to exercise rigid control over projected colleges for non-whites has caused concern and indignation in university circles throughout the Commonwealth and beyond. Some of this concern found expression in a well-attended meeting held at the Caxton Hall in London on November 2 under the sponsorship of the International Committee on Science and Freedom in co-operation with the Association of University Teachers. Dr. J. W. Cook, vice-chancellor of the University of Exeter, presided at the meeting, which by an overwhelming majority passed a resolution expressing admiration and support for those South African universities which are resisting their Government's policy and calling upon the South African Government to heed the cruel and disastrous consequences of its policy and to abstain from its further pursuit. Messages of support for the protest against university apartheid had been received from a number of organizations, including the Senatus of the University of Aberdeen, University of British
Columbia, University of the Philippines, University of the Punjab, University of Delhi, the University College of North Staffordshire, various branches of the Association of University Teachers and the National Union of South African Students.

In his introductory address, Prof. M. Polanyi, chairman of the Committee on Science and Freedom, outlined the Committee's activities during the past three years. He described the apartheid issue as one in a chain of campaigns "always the same in different form". As in other cases, the claim was made that this issue had nothing to do with academic freedom; but if it had, then academic freedom must yield to higher considerations of social interest. Prof. Polanyi suggested that it is an obligation on universities to teach young people those ideas which it is the duty of society to maintain; that any violation of these ideas within the universities cannot be tolerated; and that to demand the participation of universities in a programme of inhumanity, oppression and intellectual dishonesty is a violation of academic freedom. The general philosophy of apartheid, against the 
background of the racial composition of South Africa, was discussed by Rev. Michael Scott, honorary director of the Africa Bureau and spokesman for the African tribes in the United Nations. Apartheid, he said, has two faces: with one it looks out on the world at large, and with the other it confronts its own non-European people. To the outside world it is represented as a solution to the problem of race relationships, whereby each race is thought of as developing separately and along its own traditional lines, and within its own separate socio-economic system. To the peoples of South Africa, apartheid. means White supremacy, which in practice means Afrikaaner domination over all other peoples for the foreseeable future. During the ten years in which the Nationalist Government has been in power, the repressive aspect of apartheid has found expression in legislation for tightening of control over both physical and political movements. As several later speakers recognized, university apartheid is a natural and general development of this repressive policy.

The two main principles of this policy which emerge from the Separate University Education Bill were referred to by the next three speakers, Prof. Kenneth Kirkwood, Dr. J. W. Cook and Lord Chorley. The first new principle is the proposed creation of a system of university colleges for nonwhites (that is, Asians, Africans and coloured people of mixed origin). The colleges are to be established on a tribal basis, and the most notable feature is the very strict measure of control which the Government intends to exercise. Moreover, whereas in previous university legislation in South Africa it has been possible to dismiss the matter of misconduct by university staff in a couple of lines, in the proposed new law some 300 lines are devoted to this question. By a provision which, as Lord Chorley said, must be unique in the history of any civilized community, the staff are made retrospectively liable for misconduct committed before the date of transfer to the new regime. The position of teachers in the new institutions would be one of legal rightlessness which has scarcely been known in any free community since the serfdom of the Middle Ages. The second main principle of the Bill is the ministerial determination of the composition of the student bodies of the existing universities and the exclusion of nonwhite students in the future. These two principles are indeed supported by the majority of the academic staff of the four universities using the Afrikaans medium, but Prof. Kirkwood stressed that it is a majority and that there is no complete unanimity even in these universities. In the other four South African universities opinion is, of course, overwhelmingly against the Bill. This Bill, which received its second reading on May 27, was on the following day referred to a Select Committee.

Prof. Kirkwood, while acknowledging that there is the apartheid tradition in the Union, pointed out that there is an equally valid non-racial tradition which found its expression chiefly during the long years of British Colonial administration in South Africa, in the Cape Colony, in the Colony of Natal and elsewhere. The practice of non-racialism has been by no means confined to the English-speaking group, and it is a practice which in the universities originated more than half a century ago. Contrary to what has sometimes been suggested, it is not at the mixed universities that friction has arisen; it is in the segregated institutions that there is a sense of grievance at the denial of opportunities and facilities that are available elsewhere. Dr. Cook recalled some of the principles of self-government of the universities of the United Kingdom which are violated by the provisions of the South African University Bill, and contrasted the proposals to enforce racial segregation with the conditions which obtain at the newer university colleges in some of the British overseas territories. Of particular significance is the multi-racial character of the University College of Rhodesia and Nyasaland. The Federation adjoins the Union and has a somewhat similar racial distribution with similar social conventions.

Perhaps partly because of the ties of common ancestry with the Afrikaans-speaking population of South Africa, the Netherlands Association of University Professors and Lecturers was not officially represented, and Prof. W. T. Koiter, of Delft, emphasized that he was present in a personal capacity. But he left no doubt about the general feeling in the Netherlands universities in favour of academic freedom; and he concluded a forceful speech against the policy of apartheid with a plea to those in the South African universities who have so far supported their Government to join forces with their colleagues in the 'open' universities, and not to indulge in the illusion that academic freedom can be retained when all students are segregated according to their race.

The audience gave a polite but sceptical hearing to Prof. L. J. du Plessis, of the Potchefstroom University, who had come over from South Africa to present the case in favour of university apartheid. The principle of the scheme for compulsory separate university education, he said, has already been accepted by the Union Parliament. The matter still open for discussion in the light of the evidence to be submitted to the Commission would seem to be mainly the intensity of the Ministerial control over the non-European university colleges and the stages to be observed in the exclusion of non-European students from the existing residential universities. The new university institutions are to complete the educational structure already developed for the nonwhite groups from the elementary school stage upwards. They are meant to supply intellectual leaders for the several racial groups, and such leaders can only be satisfactorily educated in racially homogeneous institutions. Provision will be made in the near future to transfer control of Fort Hare University College and the Durban Medical School to the Government. The present situation does not give the same scope for development of non-whites as would be given in separate institutions. Prof. du Plessis conceded that the measures proposed would constitute some limitation of university autonomy, but this the State was entitled to do on behalf of over-riding national interests. In any event, control of the new institutions by Government departments is rendered necessary by the fact that the Government initially supplies all the funds, and that a responsible authority is needed to prevent undesirable ideological and other developments. Quality will be guaranteed by the University of South Africa, he said, so there is no validity in the argument that the standard of the separate institutions will be inferior. The principle of racially segregated university institutions will open the way for the employment of non-whites on an ever-widening scale in the highest university positions. 
In his brief reply to the ensuing general discussion, Prof. du Plessis said : "If I were in England, I would be an integrationist too, because it is not a danger to English national character, and if $I$ were in America I would be an integrationist too; the negroes in America are in no danger of destroying that great nation of America in its identity. But the Bantus and Indians and Coloureds of South Africa, if they are integrated moro fully than they are now, would undoubtedly destroy our great South African nation".

The general discussion, in which Prof. J. L. Montrose, Prof. A. J. Ayer, Mr. L. Behrons and others took part, was largely concerned with what steps could be taken to assist the South African univer- sities and the non-European students. Mr. T. D. Smith outlined what was being done in Oxford by the Joint Action Committee against Racial Intolerance, now a university society with more than two thousand undergraduate members, which is raising a fund to provide a scholarship for a non-white from South Africa. Dr. H. J. Grenville-Wells, who was brought up in South Africa and attended for five years a South African university, deplored the fact that she had had to come to England and go to America to meet Africans of university standard, and to find out what Africans and other coloured people want for themselves. At a meeting where plain speaking was not spared, this seemed to some the most telling indictment of apartheid.

\section{THE CHEMICAL SOCIETY OF FRANCE, I857-1957}

$\mathrm{T}$ HE centenary of the Société Chimique de France was celebrated in the Sorbonne on July 16, the President of the Republic, the Minister of Education, and the Secretaries of State for Agriculture and Public Health being present. An address was given by the president of the Society, Prof. R. Delaby, who reviewed the history of the foundation and development of the senior association of French chemists. It was foundod on June 4, 1857, on the initiative of three young chemists, Arnaudon, Collinet and Ubaldini, who, with a few other young colleagues, decided to meet weekly for the purpose of keeping in touch with all branches of the science by reading memoirs, extracts, and abstracts of work published in French and foreign journals. At that time the younger chemists of France included Wurtz, Sainte-Claire Deville, Pasteur and Berthelot. Durnas was president in 1859, Wurtz being secretary and Pasteur and Cahours vice-presidents. In 1864, the publications of the Society were united under the title of Bulletin de la Société chimique de Paris; in the same year a decreo of Napoleon recognized the Society as of public utility. By the creation of the Bulletin the Society acquired a growing influence, the enthusiasm of Wurtz being especially influential, so that he was regarded as the true founder of the Society.

When the Society was founded, the chemists of France were divided into three rival schools. That of Sainte-Claire Deville at the École Normale Supérieure continued the older traditions of Berthollet and Gay-Lussac, who were mainly interested in physical chemistry, and it continued to use the dualistic notation of Berzelius. In the Ecole de Pharmacie, Berthelot used the equivalent formulæ (as he did for long after Cannizzaro's atomic weights were accepted by other chemists). In tho École de Médecine, Wurtz was a protagonist of the new school, based on the atomic thoory, and with his collaborators, including Friedel, Ladenburg, Salet, Crafts, Grimaux, and Beilstein, used structural formulæ and the idea of chemical bonds. On account of Wurtz's influence, the new Society became the centre of interest in atomistic ideas in France. Delaby quotes what was said by Gautier on the occasion when the Society had reached its fiftieth year, to the effect that in passing from one school to another in the earlier times, a young chemist had to learn to speak a different chemical language as well as to make profound adjustments in his outlook on chemical theory.

In 1884, it was proposed that the name of the Society should be changed to Société Chimique de France, but authorization for this was not given by the Council of State until 1906, the statutes being amended accordingly. Among past presidents were three permanent secretaries of the Académie des Sciences, Dumas, Pasteur, and Berthelot, and three recipients of a Nobel Prize, Moissan, Grignard, and Sabatier. Delaby in his lecture gave brief accounts of the careers of several presidents of the Society. Dumas is best known for his discovery of substitution and homology; he was the author of a large "Traité de Chimie appliquées aux arts" and the famous "Lecons de philosophie chimique". Pasteur, a great experimenter, founded stereochemistry, and later in his researches in the fields of biochemistry and biology made important contributions to medicine. Berthelot contributed to the fields of organic synthesis, thermochemistry, the physical chemistry of the detonation wave, and the chemistry of agriculture, as well as to the history of Greek alchemy and the alchemy of the Middle Ages by the publication of texts. He also occupied important positions in the Statesenator, Minister of Public Instruction, and Foreign Secretary. Moissan worked mainly in the field of inorganic chemistry; he discovered fluorine and invented the electric furnace, with which he studied the carbides, borides and silicides of metals. Grignard is well known as the discoverer of the organomagnesium compounds and of their applications in organic synthesis. Sabatier was a pupil of Berthelot and was associated with him in many researches, but is best remembered for his process of catalytic hydrogena. tion, partly worked out with Senderens. Later notable names are Moureu, Urbain, Delepine, Matignon, and Jolibois, whose work was briefly reviewed.

Prof. Delaby's lecture gave an interesting survoy of the development of chemistry in France from about 1850 to the present day. It shows how the Société Chimique de France participated in this and how the most famous members of the Society advanced the various branches of the science. It is a record of which the French nation is justifiably proud.

J. R. Partington 